\title{
An investigation of the rarity of infantile scurvy among the South African Bantu
}

\author{
By MARIANNE ANDERSSON AND A. R. P. WALKER \\ Human Biochemistry Research Unit of the South African Institute for \\ Medical Research, Fohannesburg, and the South African Council \\ for Scientific and Industrial Research \\ AND H. C. FALCKE \\ Department of Paediatrics, Coronation Non-European Hospital, Fohannesburg
}

(Received 2 August 1955)

Various nutritional problems of Bantu infants and young children have been investigated recently at this centre. We have studied, for example, the composition of breast milk (Walker, Arvidsson \& Draper, 1954) and of the foods used at weaning (Walker, Fletcher, Strydom \& Andersson, 1955), the utilization of nutrients by infants during and after gross malnutrition (Walker, Kahn \& Reynolds, I955) and so forth. One point which has particularly impressed us is that, though in all other respects the various stigmata of malnutrition and undernutrition are such as would be expected from the inadequate diet, infantile scurvy does not apparently occur. Thus, in Johannesburg, at Baragwanath Non-European Hospital (1 $35^{\circ}$ beds), out of about 6000 admissions under 2 years of age during the last 5 years, there have been only two cases of frank infantile scurvy. At Coronation Hospital (500 beds) within the last 5 -year period, there have been only two cases of the disease among over 3000 admissions under 2 years of age.

With breast feeding, particularly when practised for protracted periods as in rural areas in Africa, there is no doubt that the amount of vitamin $\mathrm{C}$ from the milk and from the irregular amounts of fruit and vegetables provided, is sufficient to protect against the development of infantile scurvy. In urban areas, however, breast feeding is practised for shorter periods, indeed, some mothers, in their desire to get back to work quickly, wean their babies as soon as possible after parturition. In such areas, the giving of fruit and vegetables is obviously limited, and it is generally accepted as being by no means uncommon for infants to be weaned on an almost exclusive diet of cereal 'paps' or similar foods, likely to contain either very little or no vitamin C. Under conditions where infantile scurvy would be expected to occur frequently, and occasionally severely, available evidence indicates the disease to be virtually absent. Freedom from the disease cannot be ascribed to racial differences: firstly, the disease occurs among American Negro (Hess, 1920) and also Indian (Singh, 1954) infants; secondly, scurvy occurs among Bantu adults (Bronte-Stewart, 1953; Grusin \& Kincaid-Smith, I954).

In an endeavour to throw light on the subject, we have carried out an investigation on (I) Bantu infants under the age of 2 admitted to Coronation Hospital suffering 
from severe malnutrition, and (2) Bantu infants seen in the out-patients' department. Studies have included clinical and radiological observations, also determinations of the vitamin $\mathrm{C}$ concentration in the plasma of the subjects examined, and in popular baby foods prepared by Bantu mothers.

\section{EXPERIMENTAL}

\section{Subjects}

Malnourished children in hospital. The thirty-three children investigated in hospital were urban Bantu infants of ages ranging from 4 to 24 months, the mean age being I I months. Sixteen were severely malnourished, as shown by retarded growth, dyspigmentation of the skin and often of the hair, and occasionally by dermatosis and oedema. Four had gastro-enteritis, seven suffered from various infections; the remaining six had miscellaneous complaints. An X-ray examination of the femur was carried out for each child.

'Normal' Bantu infants. Twenty-nine were selected from the out-patients' department, having been brought there mainly for minor complaints or for a routine check. Their ages ranged from 4 to 18 months, the mean age being Io months.

\section{Diet}

The malnourished subjects were receiving no breast milk. Of the twenty-nine out-patient subjects, sixteen were wholly or partly breast fed; the remaining thirteen were having either very little or no breast milk. Only one patient, a malnourished subject, was said to receive fruit or vegetables regularly. The mothers of all the other infants said that such foodstuffs were given infrequently or not at all. The almost exclusive sources of nourishment were stated to be: (r) cereal 'paps' prepared with or without a little milk, (2) proprietary cereal-dried-milk mixtures prepared usually with water only, (3) dried-milk mixtures made up with water, and (4) miscellaneous mixtures (see Walker, Fletcher et al. 1955).

Samples of foodstuffs for vitamin $\mathrm{C}$ determination were collected from preparations brought by mothers for feeding their babies while waiting at the out-patients' department. A previous investigation (Walker, Fletcher et al. 1955) has revealed that such samples are representative of what urban Bantu mothers prepare at home for their young children.

\section{Methods}

In the plasma, the vitamin $\mathrm{C}$ present is usually regarded as being in transport to the erythrocytes, white cells and platelets (Bicknell \& Prescott, 1953). Plasma vitamin C is thus the most labile of fractions present in the components of the blood, and in general reflects recent intake of the substance. Since the rarity of scurvy in Bantu infants is well recognized, it was thought that a verification of this belief might be best achieved by showing that a low plasma concentration of vitamin $\mathrm{C}$ (consistent with a scorbutic state) was virtually absent in the series of subjects examined, whether malnourished or well. Accordingly, we have limited our studies to determining 
vitamin $\mathrm{C}$ concentrations in the plasma rather than in whole bood or 'buffy' layer. To determine the plasma value, $4 \mathrm{ml}$. blood were collected from the external jugular vein or from the femoral vein, usually about $3 \mathrm{~h}$ after breakfast. The blood was preserved with one drop of $30 \%(\mathrm{w} / \mathrm{v})$ potassium oxalate. In the first few determinations, two drops of $5 \%(\mathrm{w} / \mathrm{v})$ potassium cyanide were added, as recommended by Pijoan \& Klemperer (I937), but this procedure was found unnecessary when determinations were carried out within an hour of collection. Vitamin $\mathrm{C}$ was determined by the method described by King (1947). The vitamin concentration in food mixtures was determined by the method described by Kon \& Mawson (1950).

\section{RESULTS}

Results for the vitamin C concentrations in the blood plasma and in the infant foods are given in Tables $\mathrm{I}$ and 2 .

Radiological observations of the end of the femur showed no stigmata of scurvy; for example there was no evidence of the 'white line' (Bicknell \& Prescott, I953; Graham, 1952).

Table I. Vitamin $C$ concentration in the plasma of the urban Bantu infants, and values for American infants (Snelling, 1939)

Group of subjects

All infants

Severely malnourished

With gastro-enteritis

With various infections

With miscellaneous ailments
No. of subjects Infants in hospital

$\begin{array}{rcc}33 & 0.36 \pm 0.18^{*} & 0.17-0.97 \\ 16 & 0.26 & 0.20-0.41 \\ 4 & 0.42 & 0.17-0.94 \\ 7 & 0.53 & 0.36-0.80 \\ 6 & 0.41 & 0.25-0.60\end{array}$

$\overbrace{\text { Mean Range }}$

Vitamin C (mg/roo ml. plasma)

Infants attending the outpatients' department

$\begin{array}{lccc}\text { All infants } & 29 & 0.63 \pm 0.33^{*} & 0.17-\mathrm{r} \cdot 4 \mathrm{r} \\ \text { Breast-fed } & \mathrm{I} 6 & 0.80 & 0.35^{-1} \cdot 4 \mathrm{I} \\ \text { Artificially fed } & \mathrm{I} 3 & 0.42 & 0.17-1 \cdot 03 \\ & \text { American infantst } & & \\ \text { Breast-fed } & 3 \mathrm{I} & 0.76 & 0.05-\mathrm{I} \cdot 70 \\ \text { Artificially fed } & \mathrm{I27} & 0.23 & 0.08-1 \cdot 58\end{array}$

* Mean value with standard deviation.

† Among the thirty-one breast-fed infants eight were receiving orange supplements, but it was stated that there was no essential difference between groups with and without such supplementation. Among the artificially fed, seventy-nine infants given orange juice had a mean plasma concentration of $0.30 \mathrm{mg}$ vitamin $\mathrm{C}$, and forty-five with no orange juice of $0.12 \mathrm{mg}$ vitamin $\mathrm{C} / \mathrm{1} 00 \mathrm{ml}$. plasma.

Table 2. Vitamin $C$ concentration in the food preparations given to urban Bantu infants

$\begin{array}{lccc}\text { Type of food preparation } & \begin{array}{c}\text { No. of } \\ \text { samples }\end{array} & \text { Mean } & \text { Range } \\ \text { Cereal 'paps' } & 10 & 0.22 & 0-0.66 \\ \text { Proprietary cereal- } & 6 & 0.1 \mathrm{I} & 0-0.22 \\ \text { dried-milk mixtures } & & & 0-0.69 \\ \text { Dried-milk mixtures } & 6 & 0.29 & 0-0.93 \\ \text { Miscellaneous mixtures } & 6 & 0.43 & \end{array}$




\section{DISCUSSION}

The clinical picture of infantile scurvy is well known (Hess, I920; Bicknell \& Prescott, 1953; Graham, 1952). In no Bantu infant examined was there evidence of this disease. The possible presence of subclinical scurvy, however, could not be excluded.

Table $\mathrm{I}$ indicates, firstly, that the values for plasma vitamin $\mathrm{C}$ in the sick subjects were compatible with an absence of frank scurvy, and secondly, that the values in the out-patient infants were similar to those given for American subjects (Snelling, 1939). The lower mean value for the infants in hospital is presumably related to the prevalence of infections among them: twelve of the group of sixteen severely malnourished infants were suffering from gastro-intestinal disorders.

The source of the vitamin is puzzling. Its concentration in the baby foods examined was very low (Table 2). If, as we think often happens, babies are weaned exclusively on such foods, then their maximum daily intake can scarcely exceed a few milligrammes. Of the twenty-eight samples of foodstuffs examined, twelve contained no vitamin $\mathrm{C}$; from the information obtained it has been calculated that of the sixteen remaining samples eleven provided a daily intake of less than $3 \mathrm{mg}$; the other five samples provided from 4 to $8 \mathrm{mg}$ daily. Undoubtedly a large proportion of urban Bantu infants receive some vitamin $\mathrm{C}$ from fruit and vegetable sources, although all observations and inquiries made testify the irregularity of the practice. If such supplementation is the reason why scurvy among weaned or partly weaned Bantu infants is almost unknown, the implication is that all subjects examined by us, indeed, all such Bantu infants in general, are receiving supplements, which is highly improbable. Yet, the only alternative is to postulate an endogenous production of the vitamin. Further investigations to elucidate the problem are being undertaken.

\section{SUMMARY}

I. Thirty-three urban Bantu infants with severe malnutrition or other ailments necessitating hospital treatment and twenty-nine 'normal' infants attending the outpatients' department, all under 2 years of age, were examined in Johannesburg for clinical or radiological evidence of scurvy. Their plasma vitamin $\mathrm{C}$ concentration and the vitamin $\mathrm{C}$ content of the foods given to the weaned or partly weaned infants were determined.

2. No evidence of scurvy was found, and in all subjects the plasma vitamin $\mathrm{C}$ concentration was consistent with the absence of the disease, although the foods given to the infants contained very little vitamin $\mathrm{C}$.

3. It is submitted that the possibility of endogenous production of the vitamin cannot be excluded.

This paper is published with the permission of the South African Council for Scientific and Industrial Research. 
Bicknell, F. \& Prescott, F. (1953). The Vitamins in Medical Practice, 3rd ed. London: Heinemann. Bronte-Stewart, B. (1953). Quart. \%. Med. 87, 309.

Graham, G. (1952). In The British Encyclopaedia of Medical Practice, and ed., 11, 107. [Lord Horder, editor.] London: Butterworth and Co. (Publishers) Ltd.

Grusin, H. \& Kincaid-Smith, P. S. (1954). Amer. F. clin. Nutr. 2, 323.

Hess, A. F. (1 920). Scurvy, Past and Present. Philadelphia: J. B. Lippincott Co.

King, E. G. (1947). Micro-analysis in Medical Biochemistry. London: J. and A. Churchill.

Kon, S. K. \& Mawson, E. H. (1950). Spec. Rep. Ser. med. Res. Coun., Lond., no. 269.

Pijoan, M. \& Klemperer, F. (1937). F. clin. Invest, r6, 443.

Singh, A. (1954). Indian med. Gaz. 89, 288.

Snelling, C. E. (1939). F. Pediat. 15, 824.

Walker, A. R. P., Arvidsson, U. B. \& Draper, W. L. (1954). Trans. R. Soc. trop. Med. Hyg. 48, 395.

Walker, A. R. P., Fletcher, D. C., Strydom, E. S. P. \& Andersson, M. (I955). Brit. F. Nutr. 9, 38.

Walker, A. R. P., Kahn, E. \& Reynolds, P. A. (1955). Unpublished work.

\title{
The effect of vegetarianism and antibiotics upon proteins and vitamin $B_{12}$ in the blood
}

\author{
By G. A. DHOPESHWARKAR AND J. C. TRIVEDI \\ Pharmacological Research Unit of the Council of Scientific and Industrial \\ Research, Seth G. S. Medical College, Bombay, India \\ AND B. S. KULKARNI, R. S. SATOSKAR AND R. A. LEWIS* \\ Department of Pharmacology, Seth G. S. Medical College, Bombay, India
}

In a previous study of the plasma-protein pattern of a hundred normal Indian students, the authors pointed out that there was an abnormal variation in the level of albumin and a significant elevation of the globulin fraction (Satoskar \& Lewis, 1954a). Furthermore, this rise in globulin was associated with high intake of vegetable proteins. In subsequent studies it was shown that the administration of $50 \mathrm{mg}$ daily of various antibiotics over a period of 2 months led to a considerable rise in the level of albumin and a concomitant fall in the level of globulin, particularly the $\gamma$ fraction (Satoskar \& Lewis, 1954b, 1955). Studies in children, where a proportionately smaller amount of antibiotic was given, also indicated that the administration of broadspectrum antibiotics could lead to a rise in serum albumin and a fall in globulin, when the latter was higher than normal to start with (Lewis, Bhagat, Wagle, Kulkarni \& Satoskar, 1956). The present investigation was undertaken to determine if there is a difference in the blood vitamin $B_{12}$ level in vegetarians and individuals on a mixed diet, and further to study the effect of small doses of antibiotics upon the blood vitamin $B_{12}$ level and to correlate this effect with the changes in plasma proteins.

* Medical Officer of the World Health Organization. 